\title{
Attractiveness of copperleaf-based bait to leaf-cutting ants
}

\author{
Atratividade de iscas à base de acalifa para formigas cortadeiras
}

\section{Nilson Satoru Nagamoto ${ }^{I *}$ Rafael Forti Barbieri, ${ }^{\mathrm{I}}$ II Luiz Carlos Forti ${ }^{\mathrm{I}}$ Sandra Regina de Sousa Cardoso $^{\mathrm{I}}$ Sinara Maria MoreiraI Juliane Floriano Santos Lopes ${ }^{\mathrm{III}}$}

- NOTE -

\section{ABSTRACT}

Leaves of copperleaf (Acalypha spp.) are greatly accepted by leaf-cutting ants and therefore used to maintain colonies in the laboratory. In order to determine the attractive potential of granulated bait of Acalypha wilkesiana leaves versus citrus pulp, currently used in commercial baits, an evaluation was performed, by using the leaf-cutting ant Atta sexdens rubropilosa as model. The handmade non-toxic baits contained powder $(90 \% \mathrm{w} / \mathrm{w})$ of either citrus pulp or A. wilkesiana were offered simultaneously in the foraging arena until the total loading of one of them. Results showed that copperleaf baits are less attractive than the citrus ones, which invalidates the viability of the substitution.
\end{abstract}

Key words: toxic bait, Acalypha wilkesiana, Euphorbiaceae, Formicidae, leaf-cutting ant.

\section{RESUMO}

Folhas de acalifa (Acalypha spp.) são de grande aceitação pelas formigas cortadeiras $e$, por isso, utilizadas na manutenção de colônias em laboratório. Baseado nesses fatos, procedeu-se a uma avaliação da atratividade de isca granulada feita com folhas de Acalypha wilkesiana, usando a formiga cortadeira Atta sexdens rubropilosa como modelo, com o objetivo de determinar o seu potencial atrativo frente ao citros, atualmente utilizado na formulação comercial de iscas formicidas. Foram formuladas artesanalmente iscas atóxicas, contendo pó $(90 \%$ p/p) de polpa cítrica ou de A. wilkesiana. As iscas foram colocadas simultaneamente em uma arena de forrageamento até o carregamento total de uma delas. Os resultados mostram que a isca de acalifa é menos atrativa que a de citros, o que inviabiliza a substituição.
Palavras-chave: isca tóxica, Acalypha wilkesiana, Euphorbiaceae, Formicidae, saúva.

The leaf-cutting ants, Atta spp. and Acromyrmex spp. (Hymenoptera: Formicidae), are considered serious pests in the Neotropical Region since they promote defoliation in several agriculturally important crops (FOWLER et al., 1989). These ants are polyphagous but express greater preference for some plants (NAGAMOTO et al., 2009).

Among distinct control methods, granulated toxic baits (pellets) are widely used and constituted by an insecticide with delayed action (corrected mortality of workers $\leq 15 \%$ in 24 hours and $\geq 90 \%$ with 21 days) as active ingredient (AI) and an attractive substrate (NAGAMOTO et al., 2004). The high attractiveness is important so that at least the majority of the applied bait should be transported into the colony, guaranteeing the efficacy of this method (FORTI et al., 2003).

Citrus pulp is used as substrate for toxic bait production (MUDD et al., 1978) since it is very attractive, especially for ants that prefer dicotyledonous plants and that, therefore, is used as a model during prospecting for new substrates (TEIXEIRA \& SANTOS, 2008). Despite the adequacy

'Departamento de Produção Vegetal, Defesa Fitossanitária, Faculdade de Ciências Agronômicas (FCA), Universidade Estadual Paulista (UNESP), CP 237, 18610-307, Botucatu, SP, Brasil. E-mail: nsnagamoto@yahoo.com. *Autor para correspondência. IISchool of Biological Sciences, Victoria University, Wellington, New Zealand.

IIIDepartamento de Zoologia, Instituto de Ciências Biológicas (ICB), Universidade Federal de Juiz de Fora (UFJF), Juiz de Fora, MG, Brasil. 
of citrus for most leaf-cutting ant species, studies involving bait matrices continue in this direction to improve attractiveness (HUGHES et al., 2002) or search for new products to replace citrus pulp (BRUGGER et al., 2008; TEIXEIRA \& SANTOS, 2008).

Additionally, the necessities of reducing environmental impacts and optimizing energy of the productive chains while always aiming to improve the quality of the products have pressured the market to seek new alternatives in relation to farming residues (TAMMINGA, 1996). Citrus pulp is recognized as a nutritious product with high mineral content (AMMERMAN et al., 1968) and high potential for use as an animal supplement (BHATTACHARYA \& HARB, 1973), partially replacing the use of grains, which can be directed for human nutrition, thus assigning a noble role to the residue (citrus pulp).

It is known that Acalypha spp. leaves are highly attractive to leaf-cutting ants since colonies are maintained in the laboratory by using this substrate. With the objective of evaluating the potential of copperleaf as a substrate for commercial baits, the carrying processes of the following two non-toxic granulated baits were compared: $i$ ) leaves of $\boldsymbol{A}$. wilkesiana and ii) industrial citrus pulp (here used as model).

Three laboratory colonies of $\boldsymbol{A}$. sexdens rubropilosa, with about 3 to $6 \mathrm{~L}$ of fungal sponge, were being maintained principally with leaves of Ligustrum spp. and A. wilkesiana (copperleaf). Six months before the experiment, colonies started receiving only leaves of Gmelina arborea with the objective of avoiding the influence of the novelty effect (tendency toward higher preference for unfamiliar substrates: ROCES \& HÖLLDOBLER, 1994) reducing the attractiveness of A. wilkesiana. In this context, both tested baits were not familiar to the workers.

From each colony, 1L of fungus-sponge (including workers therein) was extracted in order to formulate a sub-colony without a queen. This content was put into the central chamber of our system, thus containing a set of 3 jars interconnected by pipes; two marginal chambers (in opposition at $180^{\circ}$ ) were used, one as a foraging arena and the other for disposal of the exhausted substrate (waste). The use of subcolonies instead of whole colonies is frequent (as in HERZ et al., 2008) and has the advantage of standardizing the (sub) colony population involved in the treatments.

One week after their formation, sub-colonies received both handmade granulated non-toxic formulations: a) bait with $90 \% \mathrm{w} / \mathrm{w}$ industrial citrus pulp and $b$ ) bait with $90 \%$ w/w A. wilkesiana leaves.
These baits were formulated by using the powder of these materials.

In order to produce the $\boldsymbol{A}$. wilkesiana powder new leaves were collected, firstly dehydrated in the laboratory for 2 days and subsequently in a kiln at $40^{\circ} \mathrm{C}$ for 4 hours. Immediately after, leaves were ground, by milling, and sifted. For citrus pulp, grinding and sifting were also done, but without any need for drying.

Other components for both baits were: $5 \%$ w/w refined soy oil (mean amount present in the commercial toxic baits) and 5\% w/w CMC agglomerating agent (carboxymethylcellulose), necessary to pelletize leaves. Preliminary tests (unpublished data) indicated that the CMC at $5 \%(\mathrm{w} / \mathrm{w})$ does not influence the attractiveness of granulated baits.

The formulation process consisted of mixing oil, CMC, powder, and distilled water until a pasty consistency was achieved. Fillets were produced by passing the bait paste through a syringe bulb. The syringe was a $10 \mathrm{ml}$ device with a $2 \mathrm{~mm}$ opening (Ø). Bait fillets were dehydrated in a kiln at $40^{\circ} \mathrm{C}$, packed in plastic bags and manually broken into pellets of about $0.5 \mathrm{~mm}$, similar to commercial bait pellets.

Two days before the experiment the foraging arena $(0.25 \mathrm{~L})$ was replaced by a larger one $(1 \mathrm{~L}) 12.5 \mathrm{~cm}$ in diameter. Half of the new arena, a semicircular area opposite the ants' entry point, was demarcated into two segments $\left(90^{\circ}\right.$ each). After 24 hours without substrate (G. arborea), 10 pellets of one bait type were offered in each segment and the connection to the fungus chamber was opened. Each presentation was finalized as soon as one of the treatments was totally transported by the ants and the remaining pellets were counted. Eleven presentations were carried out. Before each presentation, the foraging arena was cleaned with absolute alcohol and the position of the baits was alternated.

Presentations lasted about 30 minutes each, with a total duration about 7 hours for each sub-colony. Sub-colonies received baits on different days, within a period of 2 weeks. Until 72 hours after supplying colonies with baits an eventual rejection of the baits was evaluated in both the waste chamber and the foraging arena. In order to check the preference between citrus baits versus $A$. wilkesiana-based baits, data were submitted to ANOVA (two-way), and the means were compared by the Tukey test at $5 \%$ probability.

There was significative difference for the baits transport but the effect of colony and the colony $\mathrm{x}$ bait interaction was not significative (Table 1). The mean carrying (average \pm SE) of the citrus pellets $(9.12 \pm 0.33)$ was significatively higher $(\mathrm{P}<0.001)$ than 
Table 1 - Two-way ANOVA of the selectivity between types of bait granules in queenless sub-colonies of Atta sexdens rubropilosa.

\begin{tabular}{lccccc}
\hline Source of variation & DF & SS & MS & F & P \\
\hline Sub-colony & 2 & 23.303 & 11.652 & 3.052 \\
Bait & 1 & 68.015 & 68.015 & 17.813 \\
Sub-colony x bait & 2 & 7.848 & 3.924 & 1.028 & $<0.001^{*}$ \\
\hline
\end{tabular}

*Significant statistical values (5\% probability). DF: degrees of freedom; SS: sum of squares; MS: mean square; F: test value; P: probability value.

those of $\boldsymbol{A}$. wilkesiana (7.09 \pm 0.37$)$. No rejection of either bait was detected in any sub-colony.

Results indicate citrus baits are more attractive as than containing A. wilkesiana, although this plant species is recognized as attractive. Since lower loading could compromise ant-control effectiveness (FORTI et al., 2003) we do not recommend the utilization of $\boldsymbol{A}$. wilkesiana as a good substitute for citric pulp for commercial toxic baits.

Moreover, some substrates shown to be more attractive than citrus pulp: TEIXEIRA \& SANTOS (2008) found that the pulp of the jatoba fruit (Hymenaea courbaril) is more attractive than the citrus pulp for $\boldsymbol{A}$. sexdens rubropilosa whereas BRUGGER et al. (2008), studying Acromyrmex rugosus, observed that a neembased bait (Azadirachta indica) - made with leaves, twigs and seeds - is also more attractive, although this plant is toxic and therefore tends to be rejected later.

Additionally, the search for matrices to replace ant baits should consider not only the attractiveness of its compounds. In analysis of socioeconomic parameters, the cost-effectiveness of a new matrix should preferably exceed those presented by citrus pulp. The so-called humanistic use of foodrelated and agricultural products with high concentrations of nutrients and minerals, such as citrus pulp (AMMERMAN et al., 1968), should prioritize the optimization of the energy costs involved in the agricultural production chain (BHATTACHARYA \& HARB, 1973), redirecting a large part (if not all) of these for animal and human consumption.

Probably other substrates, as well as jatoba pulp fruit, could be more attractive than citrus. If they are economically viable, which does not seem to be the case for jatoba, and non-toxic they could be incorporated into the composition of toxic baits or even replace the citrus pulp, thus optimizing costs and disposing of agricultural residues in a nobler manner. Thus, the matrix of toxic baits for leaf-cutting ants can and should be improved.

\section{ACKNOWLEDGMENTS}

Appreciation is expressed to the anonymous referees for the critical review of the manuscript. We thank FAPESP for the postdoctoral scholarship granted (Proc. 05/ 04587-0; N.S. Nagamoto) and for partial financial support (Proc. 2005/04586-3; L.C. Forti). We also thank CNPq (Proc. 307335/2009-7; J.F.S. Lopes).

\section{REFERENCES}

AMMERMAN, C.B. et al. Nutrient and mineral composition of citrus pulp as related to production source. Proceedings of the Florida State Horticultural Society, v.81, p.301-306, 1968. Available from: <http://www.fshs.org/Proceedings/ Password\%20 Protected/1968\%20Vol.\%2081/301306\%20(AMMERMAN).pdf>. Accessed: Mar 24, 2011.

BHATTACHARYA, A.N.; HARB, M. Dried citrus pulp as a grain replacement for Awasi lambs. Journal of Animal Science, v.36, p.1175-1180, 1973. Available from: <http:// www.animal-science.org/cgi/content/abstract/36/6/1175>. Accessed: Mar 24, 2011.

BRUGGER, M.S. et al. Avaliação dos efeitos tóxicos de extrato hexânico de Azadirachta indica (A. Juss) em colônias de Acromyrmex rugosus (Smith, 1858) (Formicidae, Attini). Revista Brasileira de Zoociências, v.10, n.3, p.235-240, 2008. Available from: <http://www.editoraufff.com.br/revista/ index.php/zoociencias/article/view/35>. Accessed: Mar 24, 2011.

FORTI, L.C. et al. Eficiencia de sulfluramida, fipronil y clorpirifos como sebos en el control de Atta capiguara Gonçalves (Hymenoptera: Formicidae). Pasturas Tropicales, v.25, n.3, p.28-35, 2003. Available from: <http:// webapp.ciat.cgiar.org/forrajes/forrajeses/ pasturas_2003_25_3.htm>. Accessed: Mar 24, 2011.

FOWLER, H.G. et al. A pest is a pest is a pest? The dilemma of Neotropical leaf-cutting ants: keystone taxa of natural ecosystems. Environmental Management, v.13, p.671-675, 1989. Available from: <http://www.springerlink.com/content/ v427621378w7p382/>. Accessed: Mar 24, 2011. doi: 10.1007/ BF01868306.

HERZ, H. et al. Delayed rejection in a leaf-cutting ant after foraging on plants unsuitable for the symbiotic fungus. Behavioral Ecology, v.19, n.3, p.575-582, 2008. Available from: <http://www.ingentaconnect.com/content/oup/beheco/ 2008/00000019/00000003/art00015>. Accessed: Mar 24, 2011. doi: 10.1093/beheco/arn016. 
HUGHES, W.O.H. et al. Field evaluation of potential of alarm pheromone compounds to enhance baits for control of grasscutting ants (Hymenoptera: Formicidae). Journal of Economic Entomology, v.95, n.3, p.537-543, 2002. Available from: <http://www.bioone.org/doi/abs/10.1603/0022-049395.3.537>. Accessed: Mar 24, 2011. doi: 10.1603/0022-049395.3.537.

MUDD, A. et al. The chemical basis for the use of citrus pulp as a fungus garden substrate by the leaf-cutting ants Atta cephalotes (L.) and Acromyrmex octospinosus (Reich) (Hymenoptera: Formicidae). Bulletin of Entomological Research, v.68, p.673-685, 1978. Available from: <http://journals.cambridge.org/ action/displayAbstract ? fromPage $=$ online $\&$ aid $=2378632>$. Accessed: Mar 24, 2011. doi: 10.1017/S0007485300009639.

NAGAMOTO, N.S. et al. Method for the evaluation of insecticidal activity over time in Atta sexdens rubropilosa workers (Hymenoptera: Formicidae). Sociobiology, v.44, n.2, p.413-431, 2004. Available from: <http://cat.inist.fr/ ?aModele=afficheN\&cpsidt=16079204>. Accessed: Mar 24, 2011.
NAGAMOTO, N.S. et al. Differentiation in selection of dicots and grasses by the leaf-cutter ants Atta capiguara, Atta laevigata and Atta sexdens rubropilosa. Sociobiology, v.54, n.1, p.127138, 2009. Available from: <http://cat.inist.fr/ ?aModele=afficheN\&cpsidt=21768330>. Accessed: Mar 24, 2011.

ROCES, F.; HÖLLDOBLER, B. Leaf density and a trade-off between load-size selection and recruitment behavior in the ant Atta cephalotes. Oecologia, v.97, n.1, p.1-8, 1994. Available from: <http://www.springerlink.com/content/ q6141vn4666887q0>. Accessed: Mar 24, 2011. doi: 10.1007/ BF00317902.

TAMMINGA, S. A review on environmental impacts of nutritional strategies in ruminants. Journal of Animal Science, v.74, n.12, p.3112-3124, 1996. Available from: <http://jas.fass.org/cgi/content/abstract/74/12/3112>. Accessed: Mar 24, 2011.

TEIXEIRA, M.L.F.; SANTOS, M.N. Atratividade da isca granulada de polpa de fruto do jatobá para saúva-limão, no campo. Ciência Rural, v.38, n.4, p.907-911, 2008. Available from: <http:// dialnet.unirioja.es/servlet/articulo?codigo=2671284>. Accessed: Mar 24, 2011. 